\title{
Root growth and lignification of glyphosate susceptible and resistant soybean at low temperatures
}

\section{Crescimento e lignificação de raízes de soja convencional e resistente ao glifosato, em baixa temperatura}

\author{
Patricia da Costa Zonetti ${ }^{1 *}$; Leticia Sayuri Suzuki D’Oliveira ${ }^{2}$; Edicléia Aparecida \\ Bonini $^{3}$; Maria de Lourdes Lúcio Ferrarese ${ }^{4}$; Osvaldo Ferrarese-Filho ${ }^{4}$
}

\begin{abstract}
Low temperature stress affects plant growth, including primary and secondary metabolism. Glyphosateresistant soybean contains a modified DNA, which encodes a different type of secondary metabolism enzyme related to lignin synthesis compared to conventional glyphosate-susceptible cultivars. Thus, this soybean cultivar might respond differently to low temperatures, compared to glyphosate-susceptible cultivars. This work aimed to investigate how decreasing temperatures influence the growth and lignin content of the glyphosate-resistant soybean compared to its susceptible parental cultivars. Three-day-old seedlings were cultivated in nutrient solution at $10,15,20$, and $25^{\circ} \mathrm{C}\left( \pm 2^{\circ} \mathrm{C}\right)$, using a 12 -h photoperiod. After $96 \mathrm{~h}$, taproot growth, fresh and dry biomass, and lignin levels were determined. The results indicate that lower temperatures decreased seedling and root growth in both types of cultivars; however, glyphosate-resistant soybean exhibited greater root length, biomass, and lignin content compared to the glyphosate-susceptible parental cultivar.
\end{abstract}

Key words: Transgenic soybean, stress, phenylpropanoids

\section{Resumo}

O estresse causado pela baixa temperatura, dentre outras implicações, afeta o crescimento do vegetal assim como o seu metabolismo secundário. Pelo fato da soja RR apresentar variante enzimática de uma das principais vias do metabolismo secundário, ligada à síntese de lignina, pode apresentar comportamento diferenciado, sob baixa temperatura, se comparada com sua linhagem parental. $\mathrm{O}$ objetivo deste trabalho foi investigar possíveis diferenças no crescimento e nos conteúdos de lignina nas raízes de soja cultivar transgênica resistente ao glifosato e cultivar parental em resposta a redução de temperatura. Após três dias de germinação das sementes, as plântulas foram mantidas em solução nutritiva, a $10,15,20$ e $25^{\circ} \mathrm{C}\left( \pm 2^{\circ} \mathrm{C}\right)$, com fotoperíodo de 12 horas. Após 96 horas, foi avaliado o comprimento relativo da raiz primária, biomassa fresca e seca das raízes e os teores de lignina. Os resultados mostram que a baixa temperatura promoveu redução no crescimento das plântulas e raízes. Dentre as cultivares em estudo, a soja transgênica apresentou maior comprimento relativo, biomassas e teores de lignina.

Palavras-chave: Soja transgênica, estresse, fenilpropanóides

\footnotetext{
${ }^{1}$ Prof ${ }^{a}$ da Universidade Federal do Paraná, Campus Palotina, Palotina, PR. E-mail: patriciazonetti@ufpr.br

${ }^{2}$ Pesquisadora da Embrapa Gado de Leite, Juiz de Fora, MG. E-mail: 1suzuki@cnpgl.embrapa.br

${ }^{3}$ Prof a do Centro Universitário de Maringá, CESUMAR, Maringá, PR. E-mail: boninibio@hotmail.com

${ }^{4}$ Profs. do Dept ${ }^{\circ}$ de Bioquímica, Universidade Estadual de Maringá, UEM, Maringá, PR. E-mail: mllferrarese@uem.br; oferrarese@ uem.br

${ }^{*}$ Author for correspondence
} 


\section{Introduction}

Various environmental factors (such as water, light, and temperature) influence plant growth, development, and production. Under cultivation conditions, exposure of plants to these external environmental factors often causes stress, which may have negative influences on plants. Thus, changes to the environment may affect plant growth, and consequently crop productivity. Stress caused by low temperatures is a major issue for crops adapted to tropical and subtropical conditions (JANAS et al., 2002), including soybean (Glycine $\max (\mathrm{L}$.$) Merrill), resulting in such crops being$ highly sensitive to this type of environmental stress. For instance, normal plant growth is negatively affected at cooling temperatures, which are defined as low temperatures that are not sufficient for ice formation. Hence, cultivation at low temperatures may reduce the strength and growth of plants, even when other factors or damage are absent (RODRIGUES et al., 2001). Janas et al. (2000) observed a significant decrease in the root growth of soybean grown at $10^{\circ} \mathrm{C}$, with root elongation apparently declining after $1 \mathrm{~d}$ of exposure to this stress condition.

Exposure to low temperatures may cause physiological and biochemical changes that allow plants to adapt to stress conditions. For instance, plant secondary metabolism may change, with phenylalanine ammonia liase (PAL), which is the first enzyme in the phenylpropanoid pathway, converting phenylalanine to trans-cinnamic acid (SOLECKA, 1997; EMILIANI et al., 2009; VOGT, 2010). This pathway is the main route for the synthesis of phenolic compounds, including monolignols, which are the precursors of lignin. An increase in the activity of these enzymes facilitates the accumulation of several phenylpropanoids, as a consequence of many biotic and abiotics factors (DIXON; PAIVA, 1995).

Lignin is a highly branched phenolic polymer that is composed of phenylpropanoid alcohols
(BOUDET, 2000). Lignin corresponds to $15-30 \%$ of cell wall dry biomass, and is the second most abundant polymer in nature, after cellulose. Aside from regulating the hardness of vascular plant conductive tissues, lignin serves as a barrier against excessive water loss (BUCHANAM; GRUISSEM; JONES, 2000). This polymer is essential for joining cells, expanding and hardening tissues that function as a physical barrier against microorganism attack, and in facilitating the mechanical support of plant organs (POLLE; OTTER; SEIFERT, 1994; BOUDET et al., 2003).

Harrison et al. (1996) reported that glyphosateresistant (RR) transgenic soybean contains an inserted gene that encodes a different form of EPSP synthase (CP4-EPSP synthase). In addition to PAL, this enzyme contributes to the biosynthetic pathway responsible for the majority of secondary metabolite, aromatic amino acid, and lignin synthesis. One of the key enzymes for lignin synthesis is modified in glyphosate-resistant transgenic soybean, with the secondary metabolism of plants being potentially altered by low temperatures; hence, transgenic plant processes (i.e., lignin biosynthesis) might respond differently to low temperature stress compared to the parental cultivars. Thus, this study aimed to investigate possible differences in the root growth and lignin content of glyphosate-resistant transgenic soybean and its conventional parental cultivars in response to decreasing temperature.

\section{Material and Methods}

Seeds of the soybean (Glycine max (L.) Merrill) cultivars OC 14 (glyphosate susceptible) and CD 213RR (glyphosate resistant) were supplied by COODETEC (Cascavel, Brazil). This organization previously confirmed the presence of the CP4 EPSPS gene in CD 213RR using polymerase chain reaction (PCR). All experiments were conducted in a BOD chamber (Tecnal TE 400, Brazil) at the Plant Biochemistry Laboratory in the State University of Maringá, Paraná, Brazil. Low temperature stress 
evaluation was performed using 3-d-old seedlings, dark-germinated at $25^{\circ} \mathrm{C}$, and acclimation at 10 , 15 , or $20^{\circ} \mathrm{C}$ for $96 \mathrm{~h}$, using $25^{\circ} \mathrm{C}$ as a standard temperature. The seeds were surface-sterilized with $2 \%$ sodium hypochlorite for $3 \mathrm{~min}$, then thoroughly rinsed with deionized water, dark-germinated (at $25^{\circ} \mathrm{C}$ ) on 3 sheets of moistened filter paper rolls, and finally conditioned in flasks containing approximately $10 \mathrm{~mm}$ distilled water. The filter paper rolls were transferred to the dark chamber, which was set at $25^{\circ} \mathrm{C}$ and $80 \%$ relative humidity.

The experimental systems consisted of twentyfive 3-d-old seedlings of approximately $10 \mathrm{~cm}$ in height, which were supported on an adjustable acrylic plate, and transferred to a glass container $(10 \times 16 \mathrm{~cm})$ filled with $200 \mathrm{ml}$ of half-strength Hoagland's solution (SANTOS et al., 2004). This nutrient solution was buffered with $17 \mathrm{mM}$ potassium buffer, adjusted to $\mathrm{pH} 6.0$, and monitored over time. Containers were maintained in a growth chamber at temperatures of $10,15,20$, or $25^{\circ} \mathrm{C}(80 \%$ relative humidity, $12 / 12 \mathrm{~h}$ light/dark photoperiod, irradiance of $280 \mu \mathrm{mol} \mathrm{m} \mathrm{m}^{-2} \mathrm{~s}^{-1}$ ).

The relative length of taproots was calculated by comparing the difference in root length at the beginning of experiments and after $96 \mathrm{~h}$ of incubation for each tested temperature. Immediately after incubation, the roots were carefully blotted with absorbent paper, and the fresh weight was determined. Dry root weight was estimated after oven-drying at $80^{\circ} \mathrm{C}$, until a constant weight was obtained. The lignin content of roots was determined using the thioglycolic method (CHEN; SOMMER; MCCLURE, 2000; FERRARESE; ZOTTIS; FERRARESE-FILHO, 2002). The purest grade reagents available were used.
The experimental design was completely randomized in a factorial $2 \times 4$ (2 cultivars $\mathrm{x}$ 4 temperatures of incubation) with 4 samples. Variance and regression analysis were performed using the SAS package.

\section{Results and Discussion}

The results obtained in this study demonstrated that higher temperatures cause the taproot length of both transgenic and conventional cultivar seedlings (CD 213RR and OC 14) to increase. Each $5^{\circ} \mathrm{C}$ rise in temperature enhanced taproot growth by $3.52 \mathrm{~cm}$ and $3.25 \mathrm{~cm}$ for cultivar CD 213RR and cultivar OC 14, respectively (Figure 1). In parallel, each $5^{\circ} \mathrm{C}$ rise in temperature enhanced RR cultivar fresh and dry biomass by $0.059 \mathrm{~g}$ and $0.0232 \mathrm{~g}$, respectively. For the conventional cultivar, these values were $0.0647 \mathrm{~g}$ and $0.02718 \mathrm{~g}$, respectively (Figure 2;3).

There are different ways to measure plant growth, which may be influenced by both intrinsic and extrinsic environment factors. Low temperature is an extrinsic factor that has been reported to cause serious problems to several crops adapted to tropical and subtropical conditions. In such crops, low temperatures cause changes to cell structure, including the cell wall and plasmatic membrane (MATSUURA; OBATA, 1993), in addition to decelerated development and increased flavonoid content (LOZOVAYA et al., 2005). Acclimation of seedlings to $10^{\circ} \mathrm{C}$ causes a decline in the incorporation of polysaccharides into root cell walls. Such changes could cause irreversible damage to plants, including a reduction in cell elongation (ZABOTIN et al., 1998). On the basis of the results 
Figure 1. Seedling taproot relative length $(\mathrm{cm})$ of CD 213RR ( $(\bullet)$ and OC $14(\bullet)$ after $96 \mathrm{~h}$ of incubation in nutrient solution at 4 different temperatures under a 12 -h photoperiod.

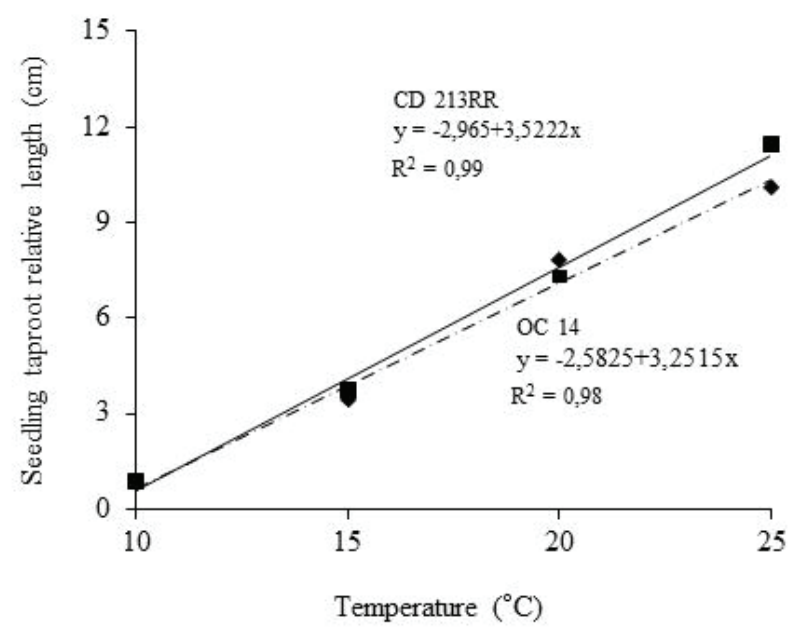

Source: Elaboration of the authors.

Figure 2. Seedling roots fresh biomass (g) of CD 213RR ( $\bullet$ ) and OC $14(\bullet)$ after 96 h of incubation in nutrient solution at 4 different temperatures under a 12-h photoperiod

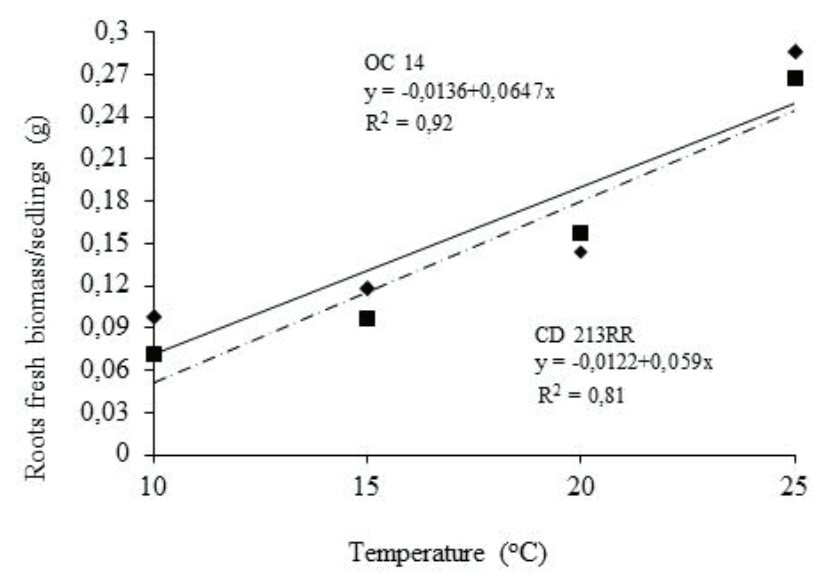

Source: Elaboration of the authors. 
Figure 3. Seedling roots dry biomass (g) of CD 213RR ( $\bullet$ ) and OC $14(\diamond)$ after $96 \mathrm{~h}$ of incubation in nutrient solution at 4 different temperatures under a 12-h photoperiod.

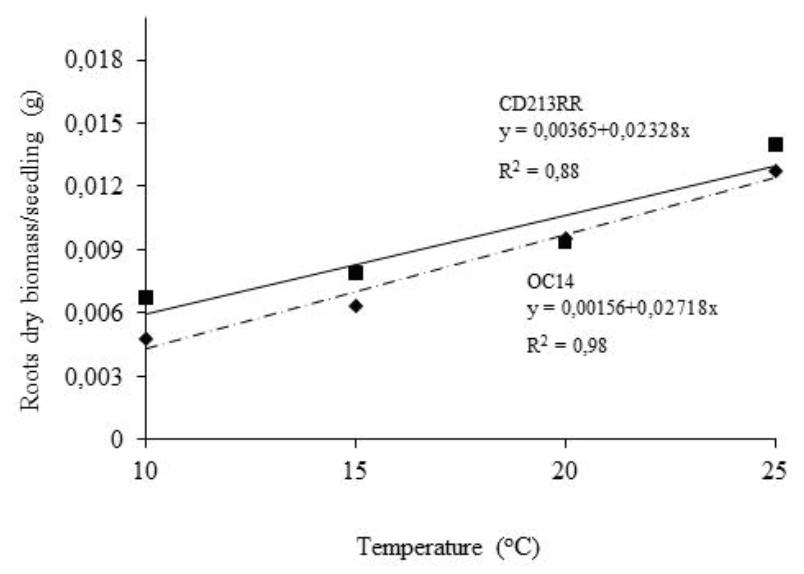

Source: Elaboration of the authors.

Obtained by Janas et al. (2000), low temperature may reduce plant relative growth without the manifestation of other stress symptoms. After $96 \mathrm{~h}$, these authors recorded a 50\% reduction in the root growth of soybean seedlings maintained in the dark and acclimated to $10^{\circ} \mathrm{C}$ compared to seedlings grown at $25^{\circ} \mathrm{C}$. In addition, Posmyk et al. (2005) observed a progressive reduction in soybean seedlings root growth and hypocotyl growth when exposed to a temperature of $1^{\circ} \mathrm{C}$. The current study also recorded a severe reduction in the taproot length of seedlings acclimated to $10^{\circ} \mathrm{C}$, compared to $25^{\circ} \mathrm{C}$. Reductions of $92.29 \%$ and $92.41 \%$ in taproot length were recorded for cultivar OC 14 and CD 213RR, respectively (Figure 1).

Following the evaluation of root growth, the lignification process was investigated at 4 different temperatures $\left(10,15,20\right.$, and $\left.25^{\circ} \mathrm{C}\right)$. The results indicated significant differences in root lignin content. Figure 4 shows that roots grown at $10^{\circ} \mathrm{C}$ contained the lowest lignin levels, with each $5^{\circ} \mathrm{C}$ increase in temperature enhancing lignin levels by $2.35 \mathrm{mg}^{2}$ LTGA $\mathrm{g}^{-1}$ and $1.87 \mathrm{mg} \mathrm{LTGA} \mathrm{g}^{-1}$ in cultivar CD 213RR and OC 14, respectively. As suggested by Janas et al. (2000), one response of plants to stress is the accumulation of phenolic compounds. Several studies have investigated how this accumulation might affect the phenylpropanoid pathway; however, the mechanism remains unclear. Janas et al. $(2000,2002)$ reported that soybean roots incubated at $10^{\circ} \mathrm{C}$ for $24 \mathrm{~h}$ exhibited enhanced levels of soluble phenolics in the cytosol. The authors observed increased levels of total phenolics, but reduced levels of cell wall-linked phenolic compounds. Furthermore, Glinska et al. (2009) reported that low temperature treatments enhanced granule-shaped phenolics levels in vacuoles. It has been agreed that reduced levels of cell walllinked phenolic compounds might modify cell wall extensibility in association with decreasing lignin synthesis velocity (POLLE; OTTER; SEIFERT, 1994; DIXON; PAIVA, 1995; SANTOS et al., 2004). As a consequence, the mechanic properties of the cell wall might change, which could break ionic and covalent linkages among the different constituents, which are primarily polysaccharides. On the basis of this theory, Zabotin et al. (1998) suggested that root growth reduction in wheat at low temperatures is associated with severe modifications in polysaccharides. Thus, polysaccharides might remain soluble if they do not form complexes with 
phenolic acids, which is an important process in plant development, and might explain the increased levels reported by Janas et al. (2000).

Despite phenolic acid levels not being determined in this work, a significant reduction in root lignification was observed in seedlings grown at low temperatures. A reduction in cell wall-linked phenolic acids in conventional soybean subjected to low temperatures was reported by Janas et al. (2000, 2002). Since phenolic acids (ferulic, $p$-cumaric, and coffeic) are associated to lignin synthesis (BUCHANAM; GRUISSEM; JONES, 2000), the development of research to quantify their levels might provide important information related to the reduced lignification observed under the lowtemperature conditions described here.

Figure 4. Lignin content (mg LTGA/g root) of CD 213RR (घ) and OC 14 ( $\bullet$ ) after $96 \mathrm{~h}$ of incubation in nutrient solution at 4 different temperatures under a 12 -h photoperiod.

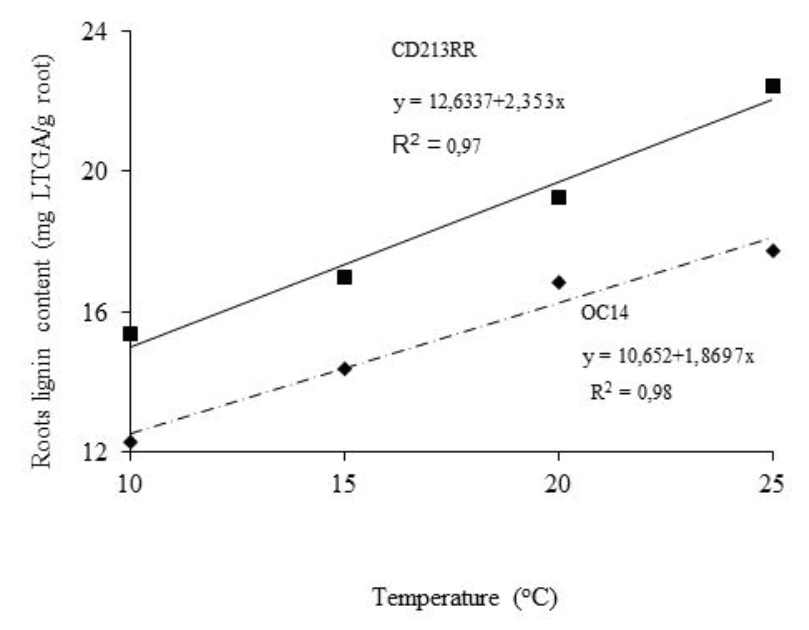

Source: Elaboration of the authors

\section{Conclusions}

Temperature elevation increased the root growth in seedlings of conventional (OC 14) and transgenic (CD 213RR) soybean cultivars, in addition to increasing lignification. However, the transgenic cultivar exhibited higher root growth and lignin content, which may enhance its tolerance to stressful low temperature conditions, compared to its conventional parental cultivar.

\section{References}

BOUDET, A. L. Lignins and lignification: selected issues. Plant Physiology and Biochemistry, v. 38, n. 1-2, p. 81-96, 2000.

BOUDET, A. L.; KAJITA, S.; GRIMA-PETTENATI, J.; GOFFNER, D. Lignins and lignocellulosics: a better control of synthesis for new and improved uses. Trends in Plant Science, v. 8, n. 12, p. 576-581, 2003.

BUCHANAM, B. B.; GRUISSEM, W.; JONES, R. L. Biochemistry \& molecular biology of plants. Rockville: American Society of Plant Physiologists, 2000. 
CHEN, M.; SOMMER, A. J.; MCCLURE, J. W. Fourier transform-IR determination of protein contamination in thioglycolic acid lignin from radish seedlings, and improved methods for extractive-free cell wall preparation. Phytochemical Analysis, v. 11, n. 3, p. 153$159,2000$.

DIXON, R. A.; PAIVA, N. L. Stress-induced phenylpropanoid metabolism. Plant Cell, v. 7, p. 10851097, 1995.

EMILIANI, G.; FONDI, M.; FANI, R.; GRIBALDO, S. A horizontal gene transfer at the origin of phenylpropanoid metabolism: a key adaptation of plants to land. Biology Direct, v. 4, n. 7, p. 1-12, 2009.

FERRARESE, M. L. L.; ZOTTIS, A.; FERRARESEFILHO, O. Protein-free lignin quantification in soybean (Glycine max) roots. Biologia, v. 57, n. 4, p. 541-543, 2002.

GLINSKA, S.; GAPINSKA, M.; GABARA, B.; MIKICINSKI, A.; SZAFRANSKA, K. Effects of chilling on the root cell ultrastructure of two soybean cultivars. Biologia Plantarum, v. 53, n. 3, p 539-544, 2009.

HARRISON, L. A. BAILEY, M. R.; NAYLOR, M.; REAM, J.; HAMMOND, D. L. The expressed protein in synthase in glyphosate-tolerant soybeans, 5-enolpyruvylshikimate-3-phosphate synthase from Agrobacterium sp. Strain CP4, is rapidly digested and is not toxic to mice upon acute gavage administration. Journal of Nutrition, v. 128, n. 3, p. 756-761, 1996.

JANAS, K. M.; CVIKROVÁ, M.; PALAGIEWICZ, A.; EDER, J. Alterations in phenylpropanoid content in soybean roots during low temperature acclimation. Plant Physiology and Biochemistry, v. 38, n. 7-8, p. 587-593, 2000.

JANAS, K. M.; CVIKROVÁ, M.; PALAGIEWICZ, A.; SZAFRANSKA, K.; POSMYK, M. M. Constitutive elevated accumulation of phenylpropanoid in soybean roots at low temperature. Plant Science, v. 163, n. 2, p. 369-373, 2002.
LOZOVAYA, V. V.; LYGIN, A. V.; ULANOV, A. V.; NELSON, R. L.; DAYDE, J.; WIDHOLM, J. M. Effect of temperature and soil moisture status during seed development on soybean seed isoflavone concentration and composition. Crop Science, v. 45, n. 5, p. 1934-1940, 2005.

MATSUURA, M.; OBATA, A. Glucosidases from soybean hydrolyze daidzin and genistin. Journal of Food Science, v. 58, n. 1, p. 144-147, 1993.

POLLE, A.; OTTER, T.; SEIFERT, F. Apoplastic peroxidases and lignification in needles of Norway spruce (Picea abies L.). Plant Physiology, v. 106, n. 1, p. 53-60, 1994.

POSMYK, M. M.; BAILLY, C.; SZAFRANSKA, K.; JANAS, K. M.; CORBINEAU, F. Antioxidant enzymes and isoflavonoids in chilled soybean (Glycine $\max (\mathrm{L}$.) Merr.) seedlings. Journal of Plant Physiology, v. 162, n. 4, p. 403-412, 2005.

RODRIGUES, O.; DIDONET, A. D.; LHAMBY, J. C. B.; BERTAGNOLLI, P. F.; LUZ, J. S. Resposta quantitativa do florescimento da soja à temperatura e fotoperíodo. Pesquisa Agropecuária Brasileira, v. 36, n. 3, p. 431437, 2001.

SANTOS, W. D.; FERRARESE, M. L. L.; FINGER, A.; TEIXEIRA, A. C. N.; FERRARESE-FILHO, O. Lignification and related enzymes in soybean root growth-inhibition by ferulic acid. Journal of Chemical Ecology, v. 30, n. 6, p. 1199-1208, 2004.

SOLECKA, D. Role of phenylpropanoid compounds in plant responses to different stress factors. Acta Physiologiae Plantarum, v. 19, n. 3, p. 257-268, 1997.

VOGT, T. Phenylpropanoid biosynthesis. Molecular Plant, v. 3, n. 1, p. 2-20, 2010.

ZABOTIN, A. I.; BARISHEVA, T. S.; ZABOTINA, O. L.; LARSKAYA, I. A. LOZOVAYA, V. V.; BELDMAN, G.; VORAGEN, A. G. J. Alterations of cell walls of winter wheat roots during low temperature acclimation. Journal of Plant Physiology, v. 152, n. 4-5, p. 473-479, 1998. 
